УДК 581.524

О. С. Комаров, В. В. Бригадиренко

Дніпропетровський національний університет

\title{
АНАЛІЗ СТРУКТУРИ ПІДТИЛКОВОЇ МЕЗОФАУНИ ЛІСОВИХ БІОГЕОЦЕНОЗІВ ПОЛТАВСЬКОЇ ОБЛАСТІ
}

На основі досліджень підстилкової мезофауни 48 обстежених лісових біогеоценозів охарактеризовано закономірності формування угруповань безхребетних на рівні видів і родин. Проаналізовано ступінь подібності пробних ділянок за таксономічною структурою герпетобію. Виявлено чинники, які впливають на формування підстилкової мезофауни лісових біогеоценозів Полтавської області.

\author{
O. S. Komarov, V. V. Brygadyrenko \\ Dnipropetrovsk National University

\section{ANALYSIS OF LITTER MESOFAUNA OF POLTAVA REGION FOREST ECOSYSTEMS}

On the basis of research of litter mesofauna of 48 forest biogeocenoses the regularities of invertebrate communities formation on the species and families levels are determined. The degree of similarity of test plots are analysed by taxonomic structure of the communities. The factors of the litter invertebrate communities formation in forest ecosystems of the Poltava region are revealed.

\section{Вступ}

Підстилка - постійне або тимчасове середовище перебування різноманітних груп безхребетних. Тваринне населення бере участь у деструкційних процесах, впливає на біологічний кругообіг підстилкового біогеогоризонту шляхом опосередкованого стимулювання активності актиноміцетів, грибів, бактерій тощо. Підстилкова мезофауна прискорює проходження екосистемою певних етапів багаторічної динаміки, на кожному з яких змінюється структура герпетобію. Дослідження особливостей формування герпетобію має практичне та загальноекологічне значення.

Зв'язки у герпетобії між популяціями підстилкових безхребетних у межах грунтово-зоологічних досліджень вивчають із застосуванням багатовимірних статистичних методів аналізу $[10 ; 12 ; 15-20]$. Ці методи дозволяють наочно виявити структуру даних, охарактеризувати фактори, під впливом яких формуються багатовидові комплекси організмів. Наприклад, тип субстрату, ступінь антропогенного порушення екосистеми, грунтову вологість і структуру рослинних угруповань виділяють як основні чинники формування комплексів турунів на території Шотландії [21].

Полтавська область розташована у центральній частині Лівобережної України. Більшу частину області (до 70 \%) займають чорноземи типові та звичайні мало- та середньогумусні. На півдні області розвинені чорноземи солонцюваті та лучночерноземні глибокосолонцюваті грунти в комплексі із солонцями; на півночі значні площі мають сірі лісові та торфоболотні грунти. Область розташована у Східно- 
Європейській лісостеповій геоботанічній провінції. Природна степова рослинність майже не збереглася. Ліси та чагарники разом із лісосмугами займають близько 7,5 \% території, головним чином уздовж берегів річок, на піскових дюнах і балках [13].

Для визначення пробних ділянок ми застосували типології природних і штучних лісів степової зони, оскільки регіон розташований на межі лісової (де застосовується типологія П. С. Погребняка [14]) та степової зон (в умовах якої використовується типологія О. Л. Бельгарда [1]). О. Л. Бельгард при створенні типології природних і штучних лісів степової зони як фактори для ординації типів лісу використовував заплавність (тривалість заливання грунту під час весняних повеней), режимне зволоження (середнє багаторічне значення зволоження, що не залежить від погодних умов періоду досліджень) і трофність едафотопу (концентрацію мінеральних елементів живлення у грунтовому розчині, що пов'язана з механічним складом грунту). В умовах степової зони ордината трофності має своє продовження у вигляді галофільних дібров [1]. Ці типи лісу не відображені у типології П. С. Погребняка, тому для визначення особливостей умов існування підстилкових безхребетних у Полтавській області ми застосували типологію О. Л. Бельгарда [1].

Мета цієї роботи - визначити фактори, що найбільшою мірою впливають на таксономічну структуру підстилкової мезофауни лісостепової зони (на прикладі Полтавської області), виділити комплекси безхребетних, які однаково реагують на зміни умов середовища існування в лісових біогеоценозах лісостепової зони.

\section{Матеріал і методи досліджень}

Основою роботи послужили результати обстеження 48 варіантів природних $\mathrm{i}$ штучних лісів Полтавської області (Кременчуцький та Козельщанський райони). Кількісний облік підстилкових безхребетних у зазначених біотопах проводився протягом сезону 2006 року із використанням пасток Барбера (поліпропіленові одноразові стаканчики об'ємом 200 мл із $20 \%$ розчином $\mathrm{NaCl}$ [ [9]. Вибірку тварин проводили залежно від погодних умов через 6-7 діб. На кожній пробній ділянці функціонувало не менше 10 пасток протягом 2-3 місяців. Усі таксони підстилкового біогеогоризонту визначено до рівня родини, а домінантні групи - до виду. В обстежених біогеоценозах виявлено 536 видів, що належать до 17 рядів. Отримані дані проаналізовані методами факторного аналізу із застосуванням пакета програм Statistica 6.0 [5-8; 11].

\section{Результати та їх обговорення}

Будь-яке багатовидове угруповання має домінантні, субдомінантні та нечисленні види, функціональна роль яких визначається у тому числі їх біомасою. Нормалізація даних, проведена при їх первинній обробці [2-4; 10], дозволяє нівелювати різницю між видами (родинами) за чисельністю. Таким чином усі зареєстровані таксони мають однакове інформаційне навантаження при оціненні стану лісового біогеоценозу або визначенні його положення за типологією. Результати кластеризації заплавних і аренних лісових біогеоценозів Полтавської області за складом герпетобію на основі порівняння поширення 48 домінантних видів безхребетних (які становлять 85,3\% загальної чисельності) свідчать про відсутність виражених розбіжностей між угрупованнями тварин окремих пробних ділянок (рис. 1). Відсутні чітко відокремлені кластери, утворені угрупованнями безхребетних декількох пробних ділянок. Подібність фаун за домінантними видами змінюється поступово, без різких змін. Таким чином, кластерний аналіз мезофауни на видовому рівні не дозволяє провести ординацію угруповань, класифікувати їх за типологією лісових біогеоценозів. 
Single Linkage

Euclidean distances

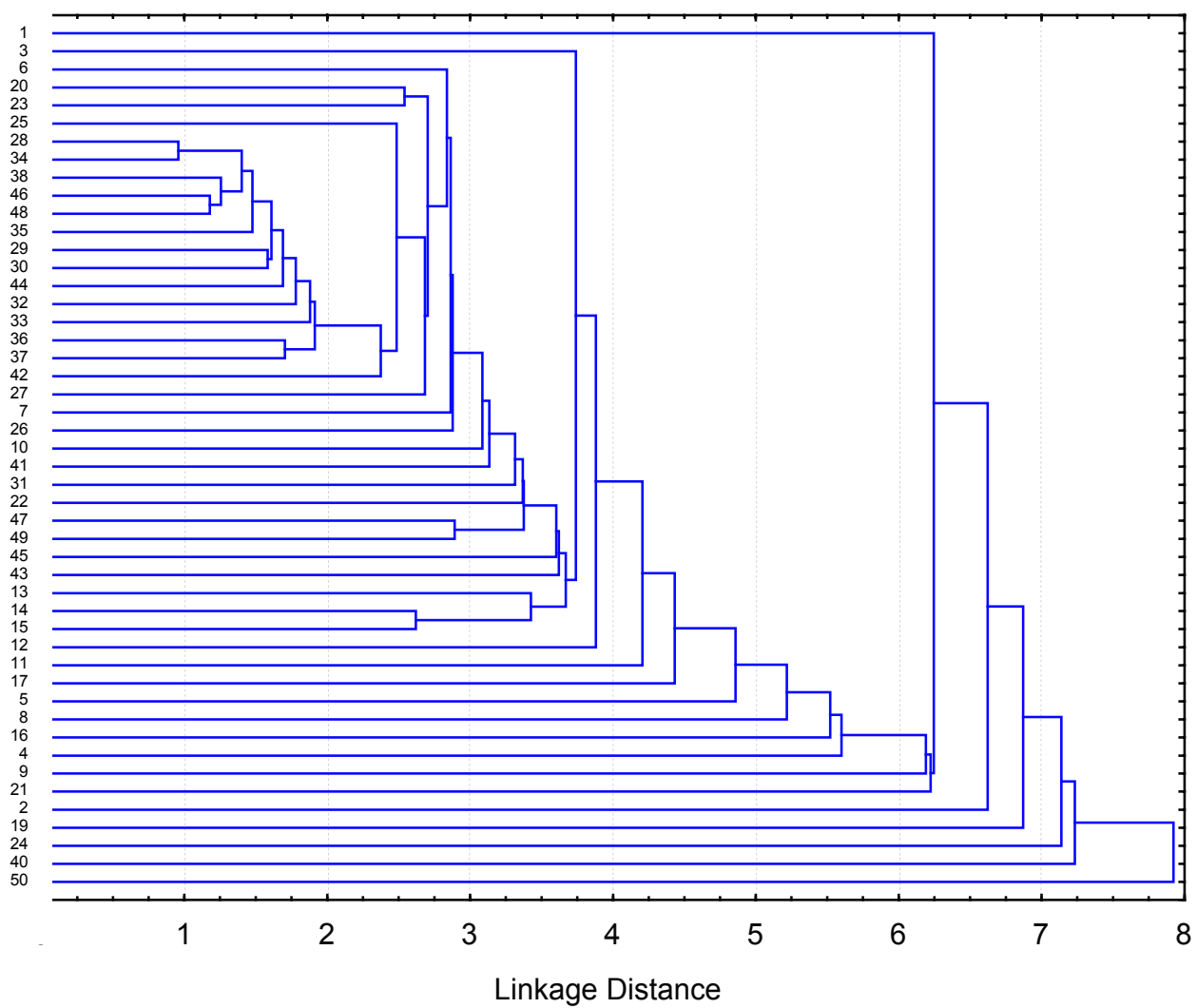

Рис. 1. Результати кластеризації заплавних і аренних лісових біогеоценозів Полтавської області за складом герпетобію на основі порівняння поширення 48 домінантних видів безхребетних тварин:

1 - Dас 2 , мезофільна штучна паклено-ясенева діброва; $2-C_{3}$, мезогігрофільний вербо-осокірник з ожиною; 3 - $B C_{2-3,}$ гігромезофільний осокірник з осокою; 4 - De $e_{3}$, мезогігрофільний вербняк з ожиною; 5 - $C_{2-3}$, осичник із гігромезофільнии різнотрав'ям; 6-AB 1 ,мезоксерофільний мертвопокривний бір; $7-B_{2-3}$, гігромезофільний бір із куничником очеретяним; $8-B_{1-2}$, осичник із ксеромезофільнии різнотрав'ям; $9-C_{5,}$ ультрагігрофільний тритичинковий лозняк із болотнии великотрав'ям; $10-B_{1-2}$, ксеромезофільний бір із куничником наземним; $11-$ Dас2, мезофільна штучна липо-ясенева діброва;

12 - Dn, мезогігрофільна в'язо-ясенева діброва із широкотрав'ям; 13 - Dез, мезогігрофільний в'язодубняк з ожиною;

$14-E_{1-2,}$ ксеромезофільний берестовий дубняк із хвилівником; 15 - De $e_{1-2,}$, ксеромезофільний в'язодубняк із хвилівником; $16-A B_{1-2,}$ ксеромезофільний шелюжник із куничником наземним; $17-E_{2-3,}$, гігромезофільний берестовий дубняк із дібровним різнотрав'ям; $19-B C_{2}$, мезофільний осокірник із стоколосом безостим; $20-A B_{2}$, мезофільний бір із зеленими мохами; $21-C_{4}$, гігрофільний тритичинковий лозняк із сирим великотрав'ям; $22-$ - $e_{4}$, гігрофільний вербняк із сирим великотрав'ям; 23 - АВ $E_{1-2,}$ ксеромезофільна бересто-ясенева діброва з грястищею; $26-A B_{1-2,}$, ксеромезофільний березняк із куничником наземним; 27 - Dn 2-з, гігромезофільна в'язова діброва з осокою; 28 - Dn 2-з, гігромезофільна в'язова діброва з ожиною; 29 - Dn, мезогігрофільна в'язова діброва з розхідником; 30 - Dас 2-з, гігромезофільна липо-ясенева діброва з широкотрав'ям; 31 $D n_{3,}$ мезогігрофільна в'язо-ясенева діброва з кропивою; 32 - Dc з, мезогігрофільна осикова діброва з конвалією; 33 - Dn, мезогігрофільна в'язо-ясенева діброва з яглищею; $34-E_{3}$, мезогігрофільна в'язо-чорнокленова діброва з розхідником; 35 $B_{1}$, мезоксерофільний дубо-сосняк із мезоксерофільним різнотрав'ям; $36-B_{2}$, мезофільний дубо-сосняк із папороттю; $37-A B_{4}$, гігрофільний бір зі сфагнумом; 38 - $B_{1-2}$, ксеромезофільна діброва з конвалією; $40-D c_{2-3}$, гігромезофільна липова діброва з широкотрав'ям; 41 - Dc2-3, гігромезофільна липо-пакленова діброва з широкотрав'ям; 42 -Dac з, мезогігрофільна липо-ясенева діброва з широкотрав'ям; 43 - Dасз, мезогігрофільна липова діброва з яглищею; 44 - Dn, гігрофільний вербняк із сирим великотрав'ям; 45 - Dас 3 , мезогігрофільна липо-ясенева діброва з широкотрав'ям; 46 - Dn, , ульт-

рахігрофільний вільшаник із болотним великотрав'ям; 47-Fel $\mathrm{l}_{-2,}$, ксеромезофільний терник із свіжуватим різнотрав'ям; 48 - Dn2, мезофільна бересто-ясенева діброва з розхідником; 49 - Dn 2-з, гігромезофільна паклено-ясенева діброва з широкотрав'ям; 50 - Dn, гігрофільний вільшаник із сирим великотрав'ям. 
На відміну від видового рівня, використання інформації про таксономічну структуру мезофауни на рівні родин дозволяє структурувати пробні ділянки на певні кластери (рис. 2). Кластер I включає біогеоценози, у яких домінують рослини роду Salix (мезогігрофільний вербо-осокірник з ожиною, ультрагігрофільний тритичинковий лозняк iз болотним великотрав'ям, гігрофільний тритичинковий лозняк із сирим великотрав'ям). На цих пробних ділянках домінують Silphidae, Porcellionidae, Byrrhidae, Chrysomelidae, Lygaeidae та відсутні такі домінантні групи як Julidae, Geophilidae, майже на третину нижча чисельність Formicidae. Імовірно це пов'язано 3 мінливим водним режимом і тривалим затопленням значної частини цих біогеоценозів.

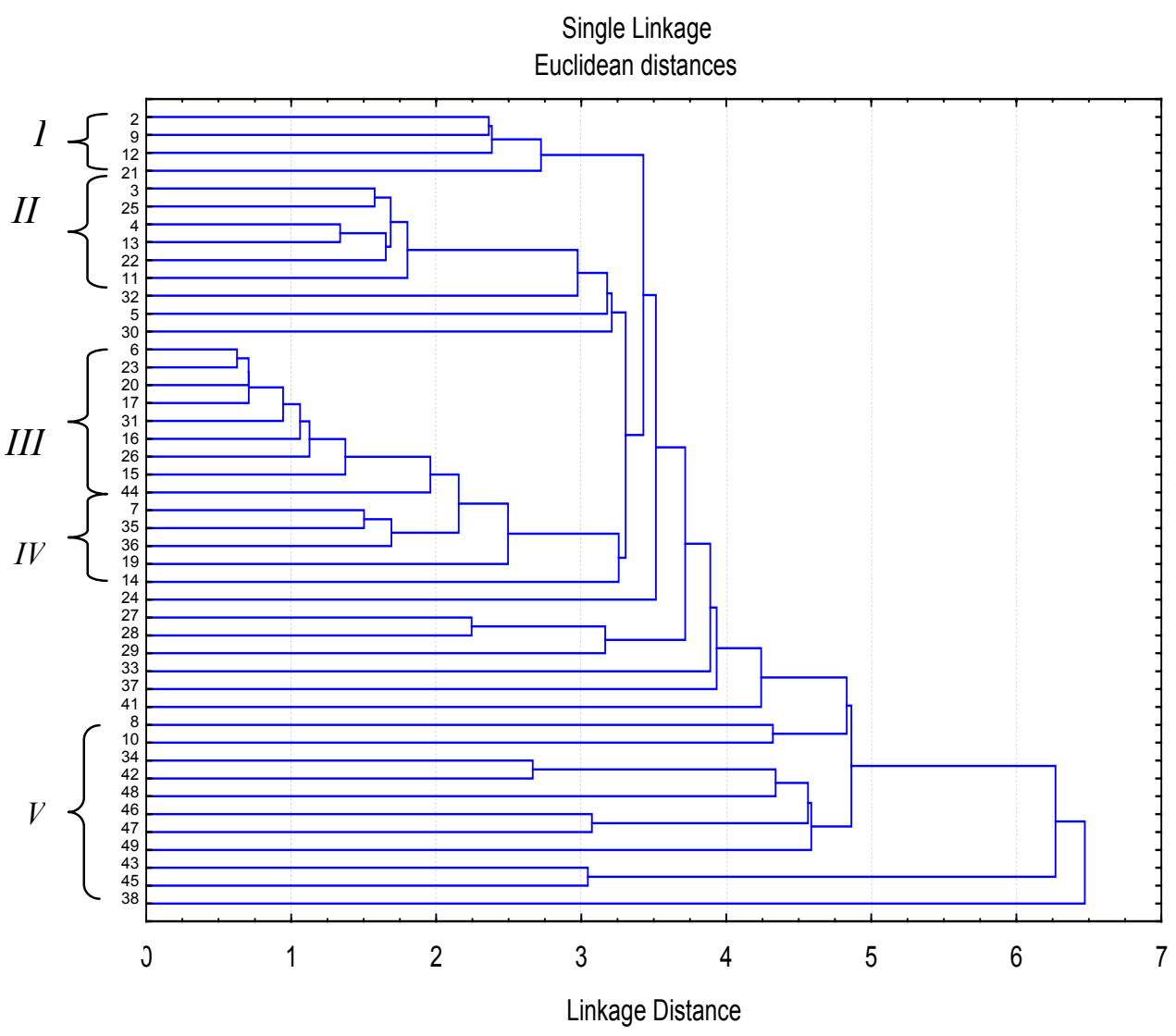

Рис. 2. Результати кластеризації заплавних і аренних лісових біогеоценозів Полтавської області за складом герпетобію на рівні родин: назви пробних ділянок відповідають наведеним на рис. 1.

Кластер II включає різні типи лісів (гігромезофільний осокірник з осокою, ксеромезофільна бересто-ясенева діброва з грястицею, мезогігрофільний вербняк з ожиною, мезогігрофільний в'язо-дубняк з ожиною, гігрофільний вербняк із сирим великотрав'ям). Але в усіх із них чисельність Cicadellidae, Porcellionidae та Formicidae значно зростає, удвічі збільшується кількість Curculionidae та Lycosidae, a Julidae, Geophilidae, Carabidae i Staphylinidae перебуває на низькому рівні.

Кластер III об'єднує типи лісу з помірним і недостатнім зволоженням (мезоксерофільний мертвопокривний бір, ксерофільний бір із лишайником, мезофільний бір із зеленими мохами, гігромезофільний берестовий дубняк із дібровним різнотрав'ям, мезогігрофільна в’язо-ясенева діброва 3 кропивою, ксеромезофільний шелюжник із ку- 
ничником наземним, ксеромезофільний березняк із куничником наземним, ксеромезофільний в'язодубняк із хвилівником). Перші три з наведених лісових біогеоценозів розташовані в аренних місцеперебуваннях, решта - у заплавних. Усі пробні ділянки, що входять до цього кластера, об'єднує велика чисельність Formicidae та Lycosidae та відсутність Tipulidae. Значно скорочується присутність Porcellionidae, Gamasidae, Cydnidae та залишається незмінною чисельність турунів.

Кластер $I V$ об'єднує сухі чи помірно зволожені аренні ділянки (гігромезофільний бір із куничником очеретяним, мезоксерофільний дубо-сосняк із мезоксерофільним різнотрав'ям, мезофільний дубо-сосняк із папороттю), на яких домінують Tenebrionidae та Curculionidae.

Досить низькою подібністю між собою за таксономічним складом мезофауни характеризуються пробні ділянки, включені до кластера $V$ (мезогігрофільна в'язочорнокленова діброва з розхідником, мезогігрофільна липо-ясенева діброва з широкотрав'ям, мезофільна бересто-ясенева діброва з розхідником, ультрагігрофільний вільшаник із болотним великотрав'ям, ксеромезофільний терник із свіжуватим різнотрав'ям, гігромезофільна паклено-ясенева діброва з широкотрав'ям). Ці пробні ділянки визначаються низькою чисельністю Formicidae, Lycosidae, Curculionidae, Staphylinidae, Silphidae та домінуванням Geophilidae, Julidae, Cydnidae та Polydesmidae.

Таким чином, використання підстилкових безхребетних тварин для зоологічної індикації умов існування в лісових біогеоценозах лісостепової зони свідчить про високий ступінь екологічної пластичності тваринних об'єктів, їх зв'язок як з абіотичними умовами існування та типологічною належністю певного типу лісу, так і з трофічними відносинами всередині герпетобію (які часто визначають склад мезофауни на рівні родин).

Для ілюстрації останнього можна використовувати аналіз усіх груп безхребетних тварин, але це не дозволяє виявити найголовніші трофічні та конкурентні зв'язки усередині герпетобію. Як вихідні дані для кластерного аналізу доцільно використовувати лише домінантні за чисельністю групи тварин. Тому ми виділили 23 домінантних родини з 93, поширених на обстежених пробних ділянках. Безхребетні тварини на рівні родин слабко пов'язані між собою (рис. 3). Окремий кластер об'єднує хижих Formicidae та Lycosidae та рослиноїдних Curculionidae (стійких до вживання в їжу першими двома групами). До іншого кластера увійшли фітофаги та сапрофаги (Porcellionidae, Cicadellidae, Lygaeidae, Chrysomelidae, Byrrhidae), поширені переважно на ділянках із недостатнім зволоженням, розвиненим трав'яним ярусом, легким механічним складом грунту. Кластер, що об'єднує подібних за способом живлення Carabidae та Staphylinidae, утворюється завдяки дуже слабким (майже повністю відсутнім) трофічним відносинам між цими групами та їх антагоністичним зв'язкам з іншими групами підстилкових зоофагів і пантофагів. Найщільнішими зв'язками у лісах лісостепової зони характеризуються сапрофаги Julidae та Pyrrhocoridae. Остання група споживає переважно трупи комах та інших безхребетних тварин.

Найслабкіші зв'язки $з$ іншими групами безхребетних тварин у Tenebrionidae. Це достатньо хітинізовані ксерофільні тварини, поширені переважно в аренних типах лісу. Привертає увагу відсутність окремого кластера, що об'єднує безхребетних, характерних для дібровних умов існування. Цікаво, що дві родини ряду Isopoda (Porcellionidae та Armadillidae) входять до різних кластерів. Імовірно це пов'язано зі здатністю Porcellionidae жити у посушливіших умовах порівняно з Armadillidae.

Таким чином, дендрограма кластерного аналізу герпетобію на рівні родин ілюструє розподіл безхребетних за пробними ділянками, їх прямі трофічні зв'язки та конкурентні взаємовідносини, опосередковані спільними джерелами живлення. 


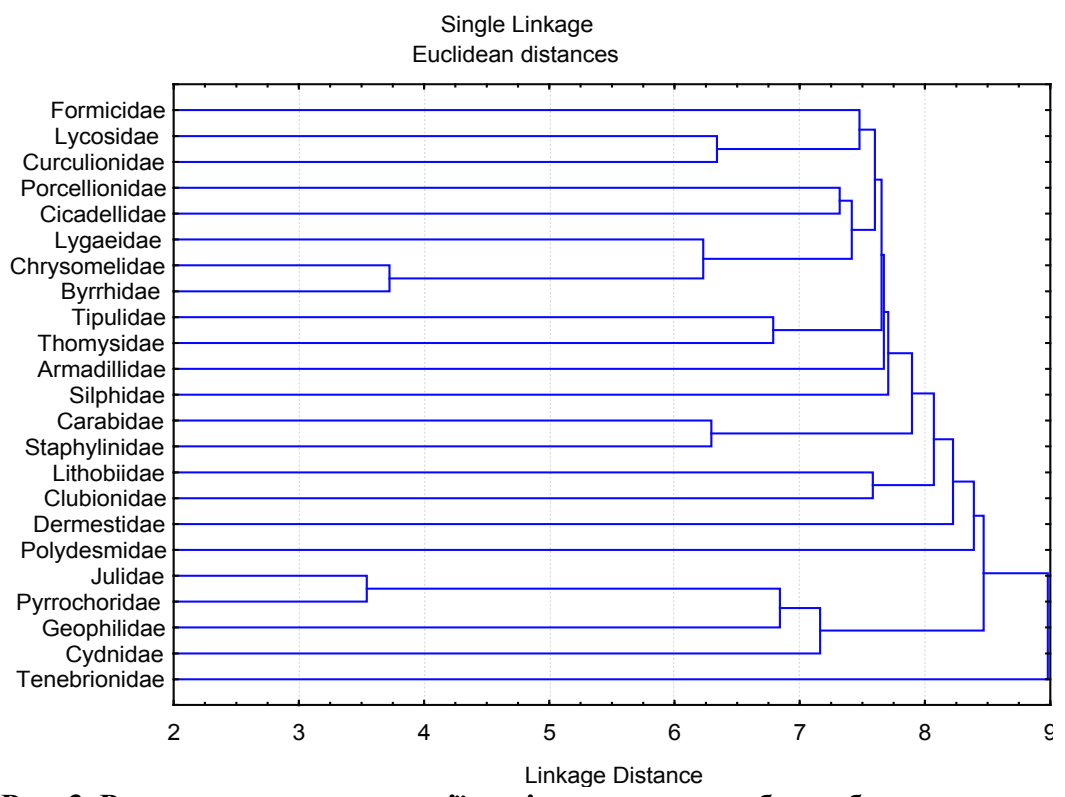

Рис. 3. Результати кластеризації домінантних родин безхребетних тварин за їх поширенням на 48 заплавних і аренних лісових біогеоценозах Полтавської області.

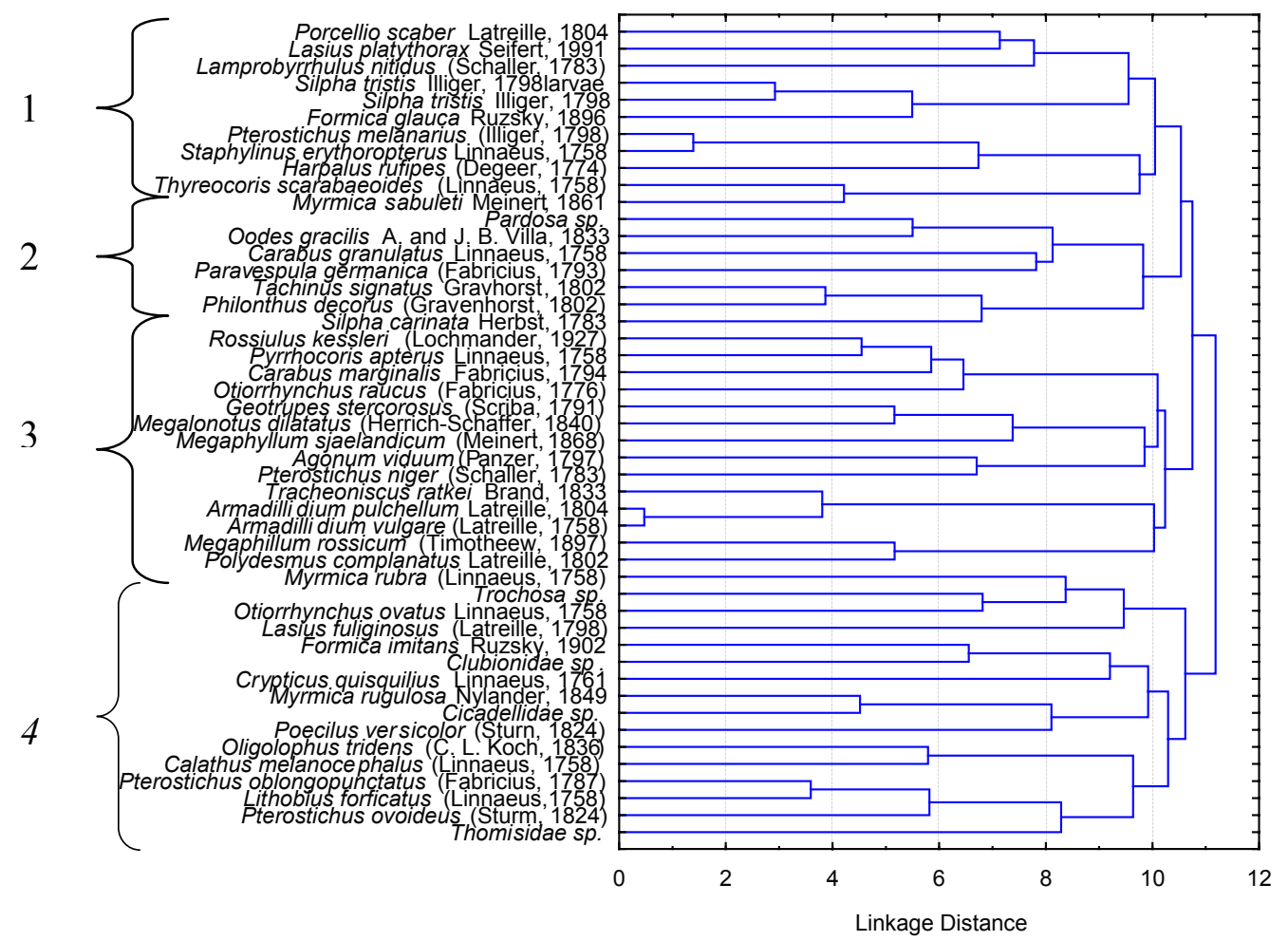

Рис. 4. Результати кластеризації домінантних видів безхребетних тварин

за їх поширенням на 48 заплавних і аренних лісових біогеоценозах Полтавської області.

Кластерний аналіз можливо проводити як на рівні родин, так і на рівні видів. В останньому випадку екологічна ніша в діапазоні певних екологічних чинників значно вужча [4]. За поширенням на певних пробних ділянках домінантні види об'єднані у 116 
кластери (рис. 4). До першого кластера увійшли комахи, що мешкають переважно в антропогенно трансформованих біогеоценозах (Pterostichus melanarius (Illiger, 1798), Harpalus rufipes (De Geer, 1774), Staphylinus erythropterus Linnaeus, 1758, Porcellio scaber Latreille, 1804, Lasius platythorax Seifert, 1991 тощо). Слід звернути увагу на об’єднання імаго та личинок Silpha tristis Illiger, 1798, що підтверджує відсутність розбіжностей у поширенні різних стадій розвитку цього виду та правомірність проведеного кластерного аналізу.

У другому кластері згруповані види тварин, широко розповсюджені у дібровних лісових угрупованнях з оптимальним і надмірним зволоженням грунту. Це Pardosa sp., Carabus granulatus Linnaeus, 1758, C. marginalis Fabricius, 1794, Tachinus signatus Gravenhorst, 1802, Philonthus decorus (Gravenhorst, 1802), Silpha carinata Herbst, 1783.

Третій кластер об'єднує Pyrrhocoris apterus Linnaeus, 1758, Agonum viduum (Panzer, 1797), Rossiulus kessleri (Lochmander, 1927), Megalonotus dilatatus (HerrichSchäffer, 1840), Geotrupes stercorosus (Scriba, 1791) та інші види.

До четвертого кластера віднесено тварин, переважна кількість яких, за результатами наших досліджень, часто зустрічається в аренних типах лісових біогеоценозів [9]: мурашки (Formica imitans Ruzsky 1902, Lasius fuliginosus (Latreille, 1798), Myrmica rugulosa Nylander, 1846), павуки (з родин Thomysidae та Clubionidae) і туруни (Calathus melanocephalus (Linnaeus, 1758), Poecilus versicolor (Sturm, 1824), Pterostichus oblongopunctatus (Fabricius, 1787), P. ovoideus (Sturm, 1824)). Також треба звернути увагу на присутність у цьому кластері рядів Opiliones та Lithobiidae.

\section{Висновки}

Результати кластеризації заплавних і аренних лісових біогеоценозів Полтавської області за поширенням 48 домінантних видів безхребетних свідчать про відсутність виражених розбіжностей між угрупованнями тварин окремих пробних ділянок. Аналіз підстилкової мезофауни на рівні родин свідчить про високий ступінь пластичності тваринних об'єктів, їх зв'язок як з абіотичними умовами існування та типологічною належністю певного типу лісу, так і з трофічними відносинами всередині герпетобію (які часто визначають їх склад).

\section{Бібліографічні посилання}

1. Бельгард А. Л. Лесная растительность юго-востока УССР. - К.: КГУ, 1950. - 264 с.

2. Бригадиренко В. В. Воздействие условий среды на состав животного населения подстилки и фитоценоз лесных экосистем степной зоны Украины // Лісівництво і агролісомеліорація. - Вип. 106. - Харків: УкрНДІЛГ, 2004. - С. 77-83.

3. Бригадиренко В. В. Закономерности распределения подстилочных беспозвоночных степных экосистем центрального степного Приднепровья // Вісник Дніпропетр. ун-ту. Біологія. Екологія. - 2004. - Вип. 12, т. 1. - С. 13-18.

4. Бригадиренко В. В. Экологические аспекты взаимодействия муравьев (Hymenoptera, Formicidae) с подстилочными беспозвоночными в условиях степных лесов // Питання степового лісознавства та лісової рекультивації земель. - Д.: ДНУ, 2005. - Вип. 9 (34). C. $181-192$.

5. Дюран Б. Кластерный анализ / Б. Дюран, П. Оделл. - М.: Статистика, 1977. - 128 с.

6. Жамбю М. Иерархический кластер-анализ и соответствия. - М.: Финансы и статистика, 1988. $-342 \mathrm{c}$.

7. Иберла К. Факторный анализ. - М.: Статистика, 1980. - 367 с.

8. Ким Д.-О. Факторный, дискриминантный и кластерный анализ / Д.-О. Ким, Ч. У. Мюллер, У. Р. Клекка. - М.: Финансы и статистика, 1989. - 215 с. 
9. Комаров О. С. Особливості формування фауни підстилкових безхребетних аренних лісів ріки Дніпро в умовах Полтавської області / О. С. Комаров, В. В. Бригадиренко // Екологія та ноосферологія. - 2008. - Т. 19, № 1-2. - С. 59-68.

10. Коросов А. В. Экологические приложения компонентного анализа. - Петрозаводск: Петрозавод. гос. ун-т, 1996. - $152 \mathrm{c.}$

11. Лоули Д. И. Факторный анализ как статистический метод / Д. И. Лоули, А. Э. Максвелл. М.: Мир, 1967. - 144 с.

12. Мендель И. Д. Кластерный анализ. - М.: Финансы и статистика, 1988. - 176 с.

13. Никифоров В. В. Экологическая сеть Среднего Придніпров'я: современное состояние и пути ее оптимизации. - Д.: ДГУ, 2003. - 187 с.

14. Погребняк П. С. Основы лесной типологии. - К.: Изд-во АН СССР, 1954. -456 с.

15. Carabid beetles (Coleoptera, Carabidae) as indicators of hydrological site conditions in floodplain grasslands / M. Gerisch, A. Schanowski, W. Figura et al. // International Review of Hydrobiology. - 2006. - Vol. 91, N 4. - P. 326-340.

16. Deichsel R. Species change in an urban setting - ground and rove beetles (Coleoptera: Carabidae and Staphylinidae) in Berlin // Urban Ecosystems. - 2006. - Vol. 9, N 3. - P. 161-178.

17. Derunkov A. V. Staphylinidae (Coleoptera) of the Pripiat river floodplain, National park "Pripiatsky", Belarus // Acta Lituanica. - 2004. - Vol. 14, N 4. - P. 14-22.

18. Halme E. Carabid beetles in fragments of coniferous forest / E. Halme, J. Niemela // Ann. Zool. Fennici. - 1993. - Vol. 30. - P. 17-30.

19. Lobo J. M. Variation in dung beetle (Coleoptera: Scarabaeoidea) assemblages with altitude in the Bulgarian Rhodopes Mountains: a comparison / J. M. Lobo, E. Chehlarov, B. Gueorguiev // Eur. J. Entomol. - 2007. - Vol. 104. - P. 489-495.

20. MeCune B. Multivariate analysis of ecological data / B. MeCune, M. J. Mefford. - MjM Software, 1999. $-237 \mathrm{p}$.

21. The relationship between the classification of scottish ground beetle assemblages (Coleoptera, Carabidae) and the National Vegetation Classification of British plant communities / S. Blake, D. I. McCracken, M. D. Eyre et al. // Ecography. - 2003. - Vol. 26, N 5. - P. 602-616.

Надійшла до редколегії 25.08.2007 